\title{
Het belemmeren van buitenlandse financiering van geloofsgemeenschappen
}

\section{Een grondrechtengevoelige kwestie}

\author{
Adriaan Overbeeke
}

De Nederlandse regering is voornemens beleid te ontwikkelen dat moet toelaten geloofsgemeenschappen te belemmeren steun te ontvangen vanuit het buitenland indien deze steun afkomstig is uit zogenoemde 'onvrije landen'. In het artikel betoogt de auteur dat beperkende maatregelen op dit terrein raken aan de onder meer door het Europees Verdrag voor de rechten van de mens (EVRM) beschermde collectieve vrijheid van godsdienst, maatregelen die enkel onder strikte voorwaarden gerechtvaardigd kunnen worden in het licht van de in artikel 9 EVRM gegarandeerde godsdienstvrijheid.

\section{Inleiding}

In de juridische vormgeving van de Nederlandse kerk-staatverhoudingen wordt een nieuw hoofdstuk geschreven. Na het 'slaken van de zilveren koorde' - het stopzetten van directe staatsfinanciering van geloofsgemeenschappen, een aspect van de ontvlechting van kerk en staat ${ }^{1}$ - worden in 2018 voorbereidingen getroffen om voortaan buitenlandse financiële steun aan te pakken. Hierbij moet worden gedacht aan problematisch geachte islamitische, met name salafistische, religie-uitoefening.

De discussie over buitenlandfinanciering van moskeeën is al langer gaande, ${ }^{2}$ maar laaide op in de zomer van 2016, in de nasleep van de politieke onrust in Turkije. Het leverde een breed gesteunde Kamermotie op, die opriep tot het introduceren van een op één land, Turkije, gericht financieringsverbod. ${ }^{3}$ De regering wees dit van de hand, met het argument dat hier de godsdienstvrijheid in het geding is. ${ }^{4}$ De in 2017 aangetreden coalitie van VVD, CDA, D66 en CU kon zich uiteindelijk

1 Zie P. van Sasse van Ysselt, 'Financiële verhoudingen tussen overheid, kerk en religieuze organisaties', Tijdschrift voor Religie, Recht en Beleid 2013, 1, p. 65-86, i.h.b. p. 66-68.

2 Dit al in 1981: zie C. Brand, “Moorse minaretten' op kosten van de staat? Overheidssubsidie voor moskeeën (1960-1990)', in: C. C. van Baalen (red.) e.a., Jaarboek Parlementaire Geschiedenis 2005. God in de Nederlandse Politiek, Den Haag 2005, p. 82. Zie ook de aangenomen motie Wilders c.s. (over onderzoek naar de mogelijkheid buitenlandfinanciering door fundamentalistische organisaties te weren), Kamerstukken II 2002/03, 27925, 76.

3 Motie Van Haersma Buma c.s. (over voorkomen dat gebedshuizen in Nederland worden gefinancierd door de Turkse overheid), 13 september 2016, Kamerstukken II 2015/16, 32824, 155.

4 Kamerbrief regering 5 juli 2016, Kamerstukken II 2016/17, 29614, 52; Kamerbrief regering 4 december 2016 over ongewenste (buitenlandse) financiering van instellingen en activiteiten, Kamerstukken II 2016/17, 29614, 56. 
vinden in de introductie van een stelsel waarin financiering vanuit een bredere categorie 'onvrije' landen zal worden bemoeilijkt, om te voorkomen dat 'vanuit het buitenland via geldstromen naar (...) religieuze organisaties onwenselijke invloed wordt gekocht'. ${ }^{5}$ Aansluitend worden de middelen daartoe geformuleerd: 'Daartoe zullen deze geldstromen meer transparant gemaakt worden. (...) Geldstromen vanuit onvrije landen, waarbij misbruik wordt gemaakt van onze vrijheden, zullen zoveel mogelijk worden beperkt. ${ }^{6}$ De coalitie zet de regering sedertdien aan om dit voornemen snel uit te voeren. ${ }^{7}$ Minister Koolmees zegde de Tweede Kamer tegen het najaar van 2018 een verkenning toe over de mogelijkheden daartoe. ${ }^{8}$

Ook lokale overheden nemen stelling op dit bijzondere terrein van staatsinterventie in religieuze aangelegenheden, waarin nog niet was voorzien in de toch veelomvattende VNG-handreiking Tweeluik religie en publiek domein. ${ }^{9}$ Zo schreef burgemeester Halsema de Amsterdamse gemeenteraad vlak na haar aantreden: 'Het is niet acceptabel als Amsterdamse burgers door een buitenlandse overheid met financiële en politieke middelen worden overreed of gedwongen om geloofsopvattingen aan te hangen of uit te dragen. ${ }^{\text {'10 }}$ Eerder deed de Haagse burgemeester Krikke een oproep aan het kabinet om met wetgeving te komen om ongewenste financiering van moskeeën te bestrijden. ${ }^{11}$

De hernieuwde belangstelling voor financiering van religieuze instellingen is een afgeleide van de al langer aanwezige zorg over de verkondiging in gebedshuizen van islamitische gemeenschappen. De opvattingen die in preken verkondigd worden, zouden samen kunnen hangen met gedachtegoed dat gemeengoed is bij de (buitenlandse) geldschieters. Hierbij zijn er twee verschillende soorten opvattingen die met zorg door de Nederlandse overheid worden gevolgd: salafistische en nationalistische. Bij de eerste categorie krijgen vooral geldstromen uit landen uit de Golfregio de aandacht. De tweede categorie bleef lang uit beeld, maar richtte zich vanaf 2016 vooral op de Turkse moskeeën in Nederland die zijn gelieerd aan het Turkse ministerie van Religieuze Zaken, kortweg Diyanet, en waar wekelijks uniforme - in Ankara geschreven - preken worden uitgesproken. ${ }^{12}$ Deze moskeeën werd ook verweten een rol te spelen in de opgelopen spanning in de Turkse diaspora in Nederland na de mislukte militaire coup tegen de Turkse president

5 Vertrouwen in de toekomst. Regeerakkoord 2017-2021, 10 oktober 2017, p. 4.

6 Idem.

7 Zie de coalitie-breed ingediende motie van het lid Beckers c.s. (over beperken van buitenlandse beïnvloeding), 14 maart 2018, Kamerstukken II 2017/18, 32824, 215 (Integratiebeleid).

8 Toezegging tijdens het debat d.d. 30 mei 2018, Handelingen II 2017/18, 87, item 3, p. 27.

9 J.E. Overdijk-Francis \& P.M. van den Eijnden (eindred.), Tweeluik religie en publiek domein. Handvatten voor gemeenten, Den Haag: VNG-Ministerie van BZK 2009, p. 55.

10 Burgemeester Halsema, Raadsbrief aanpak radicalisering, 22 augustus 2018, p. 3.

11 Bericht 'Haagse burgemeester roept kabinet op met wet te komen om ongewenste financiering moskeeën te bestrijden', de Volkskrant 30 april 2018, via www.volkskrant.nl/nieuws-achtergrond/ haagse-burgemeester-roept-kabinet-op-met-wet-te-komen-om-ongewenste-financieringmoskeeen-te-bestrijden be651d1d/.

12 Zie Aanhangsel Handelingen II 2017/18, 1929, antwoord op vragen van het lid Becker (VVD) aan de minister van Sociale Zaken en Werkgelegenheid over het bericht dat Turkije een jihadpreek dicteert in Nederland (ontvangen 30 april 2018). 
Erdogan in 2016. ${ }^{13}$ Die zorg om de nationalistische (lees: Turkse) tendensen in Nederlandse moskeeën vormde wellicht ook de directe aanleiding om religiefinanciering centraal tot beleidskwestie te verheffen.

De financieringskwestie staat niet op zichzelf. Vergelijkbare vormen van voorgenomen controle op de islam in Nederland zijn er voor wat betreft de voor giftenaftrek belangrijke anbi-status (ontnemen van deze status van algemeen nut beogende instelling aan bepaalde geloofsgemeenschappen), ${ }^{14}$ de bijzondere positie van kerkgenootschappen in het rechtspersonenrecht (het verruimen van de mogelijkheden tot ontbinding en verbod), ${ }^{15}$ de vrijheid om buiten schooltijd op eigen cultuur en religie gericht onderwijs te verstrekken (bezwaar tegen weekendscholen), ${ }^{16}$ en de wens van de coalitie om onder meer door het van overheidswege aanknopen van contacten met acceptabel geachte geloofsgemeenschappen om radicalisering te voorkomen. ${ }^{17}$ Op lokaal vlak speelde in 2018 bovendien (opnieuw) de discussie over beleid dat aanstuurt op het gebruik van de Nederlandse taal bij erediensten. ${ }^{18}$ Deze ontwikkelingen passen in wat wel de 'securitizering' van religie wordt genoemd ${ }^{19}$ de tendens dat (vooral islamitische) religieuitoefening voorwerp wordt van veiligheidsbeleid. ${ }^{20}$

In dit artikel wordt het vraagstuk van de buitenlandfinanciering nader besproken. Eerst worden de historiek van het huidige debat en de traditie van grensoverschrijdende religiefinanciering beknopt geschetst. Vervolgens worden enkele

13 Zie Aanhangsel Handelingen II 2017/18, 1930, antwoord op vragen van de leden De Graaf en Wilders (beiden PVV) aan de minister van Sociale Zaken en Werkgelegenheid over het bericht 'Nederturken klaarstomen voor carrière' (ontvangen 30 april 2018).

14 Zie Kamerstukken II 2017/18, 34785, 74 (wijziging van enkele belastingwetten en enige andere wetten (Belastingplan 2018)); antwoord op vragen van het lid Omtzigt (CDA) aan de staatssecretaris van Financiën over de publicatieplicht van moskeeën en kerken die de anbi-status hebben en de transparantie van geldstromen uit onvrije landen (ontvangen 29 januari 2018), Aanhangsel Handelingen II 2017/18, 978. Literatuur: R. Steenvoorde, 'In het algemeen belang? Het algemeen nut-criterium in recente wetgeving en jurisprudentie met betrekking tot kerken en religieuze instellingen', Tijdschrift voor Religie, Recht en Beleid 2011, 1, p. 30-42; Van Sasse van Ysselt 2013, p. 81-83.

15 Zie voorstel van wet van het lid Azmani tot wijziging van Boek 2 van het Burgerlijk Wetboek in verband met aanpassing van de uitzonderingspositie van kerkgenootschappen, Kamerstukken II 2015/16, 34465.

16 Zie Aanhangsel Handelingen II 2017/18, 3118, vragen van de leden Becker en Rudmer Heerema (beiden VVD) aan de minister van Sociale Zaken en Werkgelegenheid over het bericht 'Turkije gaat weekendscholen financieren in Nederland' (ingezonden 13 augustus 2018).

17 Bedoeld zijn contacten '(...) met religieuze (...) organisaties die de vrije waarden van de democratische rechtsstaat actief bij hun achterban willen uitdragen'. Zie motie van het lid Becker c.s., Kamerstukken II 2017/18, 29754, 451 (voorgesteld 27 juni 2018).

18 Zie hierover A. Overbeeke, 'De overheid kan niet bepalen welke taal wordt gesproken in kerkdienst', Trouw 27 maart 2018.

19 Een overzicht over het Nederlandse politieke debat en de beleidsontwikkelingen tot 2017 in S.C. van Bijsterveld, 'The Netherlands', te verschijnen in: M. Kiviorg (red.), Securitization of Religious Freedom: Religion and Limits of State Control. Proceedings of the XXIXth Annual Conference. Tallinn, 16 - 19 November 2017.

20 Zie het aan deze thematiek gewijde Tijdschrift voor Religie, Recht en Beleid 2011, 2; B. de Graaf \& S. Vellenga, 'Religie en Onveiligheid' (gastredactioneel), Tijdschrift voor Religie, Recht en Beleid 2011, 2, p. 5-6. 
grondrechtelijke aspecten besproken, en ten slotte wordt de (schaarse) jurisprudentie van het Europees Hof voor de Rechten van de Mens (EHRM) op dit terrein behandeld. Op grond van het aldus geschetste juridische kader zal ten slotte gepoogd worden de balans op te maken: welke speelruimte heeft de Nederlandse overheid in het reguleren van buitenlandfinanciering van geloofsgemeenschappen?

Het voor dit vraagstuk mede relevante (en voor de mogelijkheid van een lidstaat om deze buitenlandfinanciering te blokkeren wellicht bepalende) EU-recht met betrekking tot vrij kapitaalsverkeer blijft in deze bijdrage, waarin de grondrechtelijke aspecten van de kwestie centraal staan, buiten beschouwing. ${ }^{21}$

\section{Grensoverschrijdende steun voor religie - actuele discussies, oude tradities}

\section{Een Europees probleem}

In deze bijdrage staat het Nederlandse beleid centraal. De discussie hierover past echter in een breder patroon, want ook andere Europese staten wijzigen de wetgeving met betrekking tot religiefinanciering of maken aanstalten dit te doen, en dit steeds om dezelfde redenen.

Oostenrijk heeft zijn uit 1912 daterende islamwetgeving in 2015 aangevuld met een bepaling met betrekking tot het belemmeren van financiering vanuit het buitenland, ${ }^{22}$ simultaan met een verbod op het inzetten van vanuit het buitenland gefinancierde geestelijke bedienaren. ${ }^{23}$ Deze wetgeving leverde vooraf overigens een negatief oordeel op van de UN Special Rapporteur on freedom of religion or belief en de UN Special Rapporteur on minority issues. ${ }^{24}$

Ook in Frankrijk is de kwestie aan de orde geweest (Senaatsrapport 2016), ${ }^{25}$ en in Duitsland werd hierover in 2017 in de schoot van de belangrijkste beleidspartij

21 'Op basis van het Gemeenschapsrecht is het aantal mogelijkheden om geldstromen uit lidstaten van de Europese Unie te blokkeren beperkt. Een van de belangrijkste pijlers van de Europese Unie is immers vrij verkeer van kapitaal. (...). Mede om deze reden zijn binnen het nationale recht nagenoeg geen juridische grondslagen voorhanden om ongewenste geldstromen vanuit het buitenland, binnen of buiten de EU, ter financiering van maatschappelijke of religieuze instellingen, te blokkeren. (...)' Minister van Buitenlandse Zaken, mede namens de minister van Sociale Zaken en Werkgelegenheid en de minister voor Rechtsbescherming, 29 mei 2018, Kamerstukken II 2017/18, 29614, 77, p. 4.

22 Bundesgesetz über die äußeren Rechtsverhältnisse islamischer Religionsgesellschaften - Islamgesetz 2015, BGBl. I, nr. 39/2015 (art. 6, (2): 'Die Aufbringung der Mittel für die gewöhnliche Tätigkeit zur Befriedigung der religiösen Bedürfnisse ihrer Mitglieder hat durch die Religionsgesellschaft, die Kultusgemeinden bzw. ihre Mitglieder im Inland zu erfolgen').

23 Cf. memorie van toelichting bij art. 6, (2) van het wetsontwerp. Zie ook B. Ichner, '65 Imame müssen Österreich bald verlassen', Kurier 19 februari 2016, https://kurier.at/chronik/ niederoesterreich/65-imame-muessen-oesterreich-bald-verlassen/181.800.423.

24 Brief H. Bielefeldt \& R. Izsák d.d. 31 oktober 2014. Beschikbaar via: https://spdb.ohchr.org/hrdb/ 28th/Public_-_OL_Austria_31.10.14_(1.2014).pdf.

25 Sénat, session extraordinaire 2015-2016, nr. 757, Rapport d'information fait au nom de la mission d'information (1) sur l'organisation, la place et le financement de l'Islam en France et de ses lieux de culte, juli 2016, www.senat.fr/rap/r15-757/r15-7571.pdf. In dit rapport wordt de budgettaire omvang van de buitenlandse financiering sterk gerelativeerd. 
(CDU-CSU) het debat geopend. ${ }^{26}$ Vooral Diyanet-moskeeën krijgen daarbij aandacht. ${ }^{27}$ In een onderzoeksrapport uit 2017 over de situatie in het Verenigd Koninkrijk (waar buitenlandfinanciering van moslimgemeenschappen is onderzocht) ${ }^{28}$ wordt aangegeven dat minstens het verkrijgen van transparantie op dit terrein in de optiek van de rapporteurs een belangrijk beleidsdoel zou moeten zijn. $^{29}$

Ook de Vlaamse minister van Binnenlands Bestuur Liesbeth Homans (van de Vlaams-nationalistische N-VA) is een uitgesproken voorstander van een verbod op buitenlandse financiering van moskeeën in Vlaanderen en wil daarin regelgevend optreden. ${ }^{30}$

\section{Bezorgdheid over buitenlandfinanciering in Nederland: belemmert integratie, stimuleert radicalisering}

Uit het parlementaire debat over deze aangelegenheid komt naar voren dat de motieven voor belemmerend overheidsingrijpen ingegeven zijn door een bezorgdheid over het integratie-remmende effect van een vanuit het buitenland (in het bijzonder: door vreemde overheden) gefinancierde religie-uitoefening van ingezetenen die een migratieachtergrond hebben. Dit verklaart mede dat de eerstverantwoordelijke minister in deze kwestie de minister is die integratie in de portefeuille heeft. ${ }^{31}$

De integratie-invalshoek is herkenbaar in de bezorgde opstelling van minister Asscher in 2013 in zijn antwoord op vragen over Koeweitse financiering van een Amsterdamse moskee:

'Om te komen tot een volledige integratie in de Nederlandse samenleving is het van belang dat migranten kennisnemen van de kernwaarden van de Nederlandse samenleving en deze ook verinnerlijken. Het is niet acceptabel

26 Zie (ook over de afwijzende reactie van de Duitse Bondsregering, met name ook op het punt van de vereiste dat de financiering van moskeeën niet vanuit het buitenland kan gebeuren): www.faz. net/aktuell/politik/inland/integration-bundesregierung-lehnt-islamgesetz-ab-14955328.html.

Kritisch: blog R. Polenz, Islamgesetz: Eine populistische Schnapsidee,www.huffingtonpost.de/ ruprecht-polenz/islamgesetz-populismus-cdu_b_15759304.html.

27 Zie recent: 'Verfassungsschutz prüft Beobachtung', Frankfurter Allgemeine Zeitung 20 september 2018, www.faz.net/aktuell/politik/inland/ditib-zentrale-verfassungsschutz-prueft-beobachtung -15798693.html.

28 J. Elgot, 'Theresa May sitting on report on foreign funding of UK extremists', The Guardian 3 juli 2017, www.theguardian.com/uk-news/2017/jul/03/theresa-may-report-foreign-funding-extrem ists-saudi-arabia.

29 'While Britain may not choose to introduce legislation for blocking foreign funding, measures might be considered that would oblige institutions to show more transparency on certain kinds funding from abroad.' Zie T. Wilson, Foreign Funded Islamist Extremism in the UK, Centre for the Response to Radicalisation and Terrorism, Research Paper No. 9, Henry Jackson Society 2017, p. 1.

30 Bericht 'Homans voorstander van verbod op buitenlandse financiering van moskeeën', De Morgen 21 februari 2017, www.demorgen.be/binnenland/homans-voorstander-van-verbod-op-buiten landse-financiering-van-moskeeen-b4161af6/.

31 Sinds het kabinet-Rutte III: de minister van Sociale Zaken en Werkgelegenheid. 
als zij onder druk worden gezet door buitenlandse overheden of organisaties. $^{32}$

Dit houdt niet in dat financieringsstromen, ook niet van overheden, geblokkeerd moeten worden:

'Voor buitenlandse mogendheden is het mogelijk om op basis van vrijwilligheid contact te onderhouden met (voormalige) onderdanen, zolang dit de integratie in de Nederlandse samenleving niet belemmert. Het is toegestaan om gebruik te maken van buitenlandse financiering om gebedshuizen te stichten.'33 [mijn cursivering; $\mathrm{AO}$ ]

Die conclusie wordt in latere Kamerbrieven onderbouwd. Minister Asscher schrijft de Tweede Kamer in juli 2016 (vlak voor de 'coup' in Turkije) dienaangaande:

'Uitgangspunt bij buitenlandse financiering van instellingen (religieus, maatschappelijk of anderszins) is dat dit in principe niet onwenselijk of illegaal is (... ) [mijn cursivering; AO]. Nederland kent geen algemeen verbod op buitenlandse financiering van moskeeverenigingen en -stichtingen c.q. algemene religieuze verenigingen en stichtingen. In Nederland heeft iedere geloofsgemeenschap de vrijheid om (buitenlandse) financiering aan te trekken of geloofsgenoten in het buitenland te ondersteunen. Het beperken van vrijheden van bepaalde religieuze instellingen, bijvoorbeeld door het beperken van buitenlandse financiering van deze instellingen, tast de grondwettelijke vrijheid en gelijkheid van godsdienst aan. ${ }^{34}$

De impliciet gebleven politieke boodschap onder deze op artikelen 6 en 1 van de Grondwet $(\mathrm{Gw})$ gebaseerde grondrechtenredenering is dat buitenlandfinanciering niet noodzakelijkerwijs een belemmering hoeft te vormen voor de integratie van moslims in de Nederlandse samenleving.

Deze houding onder Nederlandse politici - en later ook van het kabinet, zoals wij hierna zullen zien - verandert echter door de manier waarop de Turkse overheid reageert op de coup van juli 2016. Onder andere middels de Diyanet-moskeeën in Europa werden beschuldigende vingers gewezen naar de Gülen-beweging, die ook in Nederland een aanzienlijke aanhang heeft. In een door de Tweede Kamer breed gesteunde motie ${ }^{35}$ van fractieleiders Buma, Segers en Van der Staaij wordt vervolgens gepoogd de Turkse staatsinvloed via Diyanet terug te dringen. Diyanet telde

32 Vragen van het lid Yücel (PvdA) aan de minister van Sociale Zaken en Werkgelegenheid over het bericht dat een moskee in Amsterdam Slotervaart onder 'Koeweits gezag' staat. Aanhangsel Handelingen II 2012/13, 2728.

33 Idem. In gelijke zin: Kamerbrief 4 november 2009, Kamerstukken II 2009/10, 28844, 38 (Integriteitsbeleid openbaar bestuur en politie).

34 Kamerbrief 5 juli 2016, Kamerstukken II 2016/17, 29614, 52.

35 Motie van het lid Van Haersma Buma c.s., 13 september 2016, Kamerstukken II 2016/17, 29279, 155. 
in 2014 ruim 143 moskeeën in Nederland en benoemt en betaalt er de imams. ${ }^{36}$ Volgens de indieners van de motie staat dit financiersmodel 'op gespannen voet (...) met de scheiding van kerk en staat'. De regering wordt gevraagd 'maatregelen te nemen om te voorkomen dat gebedshuizen in Nederland worden gefinancierd door de Turkse overheid'. ${ }^{37}$ De strekking van de motie is helder: 'álle overheidsfinanciering uit één specifiek land moet worden verboden en aldus zou volgens de motie recht worden gedaan aan de scheiding van kerk en staat'.

Het onbehagen over de potentiële negatieve invloed van buitenlandfinanciering van islamitische geloofsgemeenschappen op de integratie van moslims wordt nog versterkt door (vrees voor) religieus geweld vanuit deze gemeenschap. Bij deze ontwikkeling, waarin vooral veiligheidsbehoeften centraal komen te staan, komen niet onmiddellijk migratieherkomstlanden als Turkije in beeld, maar de Golfstaten. Tot nog toe poogde de Nederlandse regering dit type 'ongewenste financiering' te ontmoedigen door afspraken met de betrokken staten, ${ }^{38}$ maar dat spoor lijkt sinds het aantreden van het kabinet-Rutte III in oktober juli 2017 te worden aangevuld met in het regeerakkoord aangekondigde maatregelen, voor zover deze Golfstaten volgens het voorgenomen nieuwe beleid in de categorie 'onvrije landen'vallen.

Het regeerakkoord is in resolute termen gesteld, maar sluit naadloos aan bij de al eerder levende zorg van het kabinet-Rutte II over, blijkens een Kamerbrief van minister van Buitenlandse Zaken Koenders, 'buitenlandse financiering die het risico vergroot op ongewenste beïnvloeding die bijdraagt aan antidemocratisch, anti-integratief en onverdraagzaam gedrag dat haaks staat op de uitgangspunten van de rechtsstaat en de waarden die in Nederland worden gekoesterd (...)'. ${ }^{39}$ Het regeerakkoord van 2017 is qua beleidsvoornemens evenmin origineel, aangezien in 2016 al gekoerst werd op het '(...) nemen van maatregelen rondom transparantie (...)' en de 'voorbereiding van wetgeving om ongewenste (buitenlandse) financiering in te perken'. ${ }^{40}$

Een belangrijk verschil tussen de twee kabinetten is wel dat Rutte II in zijn beleidsvoornemens op dit terrein uit 2016 uitdrukkelijk grondrechtelijke maatstaven hanteert, want bij het nemen van deze maatregelen vereist de regering 'de nuance en precisie die noodzakelijk zijn bij het trekken van grenzen waar het gaat om onze (soms botsende) grondrechten en vrijheden en het beginsel van de schei-

36 T. Sunier \& N. Landman, Turkse islam. Actualisatie van kennis over Turkse religieuze stromingen en organisaties in Nederland, rapport in opdracht van het ministerie van Sociale Zaken en Werkgelegenheid, 2014, p. 61 e.v.

37 Motie van het lid Van Haersma Buma c.s., 13 september 2016, Kamerstukken II 2016/17, 29279, 155.

38 Kamerbrief 4 oktober 2017, Kamerstukken II 2017/18, 29614, 62. (Grondrechten in een pluriforme samenleving).

39 Idem.

40 Kamerbrief regering 4 december 2016 over ongewenste (buitenlandse) financiering van instellingen en activiteiten, Kamerstukken II 2016/17, 29614, 56. 
ding tussen kerk en staat'. ${ }^{41}$ Die maatstaf ontbreekt in het regeerakkoord van het kabinet-Rutte III. ${ }^{42}$

Onthullingen van de NRC en het actualiteitenprogramma Nieuwsuur in het voorjaar van 2018 over de omvang van buitenlandse moskeefinanciering leidden opnieuw tot een Kamerdebat, waaruit kon worden opgemaakt dat vastgehouden wordt aan de in het regeerakkoord uitgezette koers, maar dat er onzekerheid bestaat over de mogelijke maatregelen. ${ }^{43}$

\section{Grensoverschrijdende financiering van geloofsgemeenschappen; een traditie}

De groeiende aandacht voor het sterk gearticuleerde onbehagen over het relatief nieuwe fenomeen van buitenlandse materiële steun aan godsdienstige islamitische gemeenschappen in Nederland mag niet doen vergeten dat grensoverschrijdende financiering van religie deel uitmaakt van zowel de Nederlandse protestantse als katholieke traditie. Deze inter- en intrakerkelijke christelijke solidariteit, die ook binnen de orthodoxie leeft, is geen eenrichtingsverkeer. De steun kan ook nu nog vanuit het buitenland in Nederland terechtkomen. ${ }^{44}$

Deze grensoverschrijdende solidariteit is aan te merken als een onderdeel van de geloofsuitoefening, op individueel en op collectief niveau. Die solidariteit wordt overigens door de Nederlandse overheid indirect ondersteund via de fiscale voordelen die de betrokken religieuze organisaties toekomen, met name de giftenaftrek (anbi-status). Het regeerakkoord van het kabinet-Rutte III stelt uitdrukkelijk dat aan de wettelijke regeling voor giftenaftrek niet zal worden geraakt. ${ }^{45}$

Vormen van individuele en collectieve geloofsuitoefening verdienen bescherming in het licht van het interne hoogste recht, de Grondwet, ${ }^{46}$ maar ook van mensenrechtenverdragen, met name het EVRM. De vraag is dan of de overheid bij het reguleren van de financiering van geloofsgemeenschappen in haar handelingsvrijheid beperkt wordt door haar verplichting de in het EVRM verankerde grondrechten te respecteren.

41 Kamerbrief regering 4 december 2016 over ongewenste (buitenlandse) financiering van instellingen en activiteiten, Kamerstukken II 2016/17, 29614, 56.

42 Het Regeerakkoord betrekt de grondrechten in een passage over terrorismebestrijding wel in de afweging als het gaat om repressieve maatregelen die 'noodzakelijk' moeten zijn en 'waarbij telkens kritisch afgewogen moet worden in welke mate de privacy en overige vrijheden worden ingeperkt'; Vertrouwen in de toekomst. Regeerakkoord 2017-2021, 10 oktober 2017, p. 4.

43 Zie M. Lievisse Adriaanse, "Kamer voelt “onbehagen" en "onmacht” over buitenlandse financiering moskeeën', NRC 30 mei 2018, www.nrc.nl/nieuws/2018/05/30/kamer-voelt-onbehagen-enonmacht-over-buitenlandse-financiering-moskeeen-a1604793.

44 Bijv. de middelen die diasporakerken van (o.m.) buitenlandse staatskerken vanuit het buitenland ontvangen. Dit geldt bijv. voor de Noorse en Finse kerken in Nederland.

45 Vertrouwen in de toekomst. Regeerakkoord 2017-2021, 10 oktober 2017, onderdeel '1.6 Cultuur', p. 19.

46 Met name art. 6 Gw. Zie S.C. van Bijsterveld \& B.P. Vermeulen, 'Commentaar op artikel 6 van de Grondwet', in: E.M.H. Hirsch Ballin \& G. Leenknegt (red.), Artikelsgewijs commentaar op de Grondwet, webeditie 2017 (www.Nederlandrechtsstaat.nl). 


\section{De maatstaf voor het beleid: respect voor grondrechten (EVRM)}

\section{Grondrechten van geloofsgemeenschappen in het geding}

De verhouding tussen overheid en religieuze gemeenschappen bleef aanvankelijk buiten beeld in de EHRM-jurisprudentie met betrekking tot de godsdienstvrijheid: niet de communautaire maar de individuele godsdienstvrijheid stond centraal. ${ }^{47}$ Vanaf de eeuwwisseling kwam hier verandering in en kregen collectieve aspecten van godsdienstvrijheid meer aandacht. Uit de jurisprudentie blijkt dat het EVRM aanknopingspunten biedt voor een eigen rechtspositie voor geloofsgemeenschappen. In zijn jurisprudentie heeft het EHRM de geloofsgemeenschappen, zelfstandige dragers van het recht op godsdienstvrijheid, een brede waaier aan collectieve aspecten van godsdienstvrijheid toegemeten. ${ }^{48}$ Dit brengt mee dat godsdienstvrijheid onder meer inhoudt dat:

a godsdienst door gelovigen gezamenlijk moet kunnen worden gevierd (het bijeenkomen van geloofsgenoten in een geloofsgemeenschap ${ }^{49}$ ), waarbij de overheid er zo nodig voor zorgt dat andere geloofsgemeenschappen dit tolereren (bescherming tegen molest ${ }^{50}$ );

b geloofsgemeenschappen hun geloofsgoed vrij kunnen verkondigen (extern gericht, proselitisme), preken en onderwijzen (intern gericht, bijv. door catechese), ${ }^{51}$ in de taal die ze zelf kiezen (of de taal die ze ingevolge een religieus voorschrift hanteren); 52

c geloofsgemeenschappen gelegenheid hebben daartoe een gebedshuis te bouwen of te verwerven; 53

d geloofsgemeenschappen zich vrij kunnen organiseren, ${ }^{54}$ wat onder meer betekent dat ze uitmaken wie ertoe behoren of niet (kwesties in verband met individueel lidmaatschap), tot welk groter verband ze al dan niet wensen toe te treden ${ }^{55}$ of van welk verband ze afscheid willen nemen; ${ }^{56}$

47 Zie B.P. Vermeulen \& M. van Roosmalen, 'Freedom of thought, conscience and religion (Article 9)', in: P. van Dijk e.a. (red.), Theory and Practice of the European Convention on Human Rights, Antwerpen: Intersentia 2018, p. 735-763, i.h.b. p. 741-747.

48 Vermeulen \& Van Roosmalen 2018, p. 748-755.

49 EHRM 13 december 2001, nr. 45701/99, Metropolitan Church of Bessarabia e.a./Moldavië; EHRM 27 januari 2011, nr. 77185/01, Boychev/Bulgarije; EHRM 24 mei 2016, nr. 36915/10, Association de solidarité avec les témoins de Jéhovah e.a./Turkije.

50 EHRM 3 mei 2007, nr. 71156/01, Members of the Gldani congregation of Jehovah's Witnesses e.a./Georgië.

51 EHRM 25 mei 1993, nr. 14307/88, Kokkinakis/Griekenland.

52 Af te leiden uit ECieRM (Europese Commissie voor de Rechten van de Mens), beslissing 11 april 1996, nr. 24019/94, Finska församlingen i Stockholm en T. Hautaniemi/Zweden.

53 EHRM 26 september 1996, nr 18748/91, Manoussakis e.a./Griekenland.

54 EHRM 14 december 1999, nr. 38178/97, Serif/Griekenland; EHRM 26 oktober 2000, nr. 30985/96, Hasan \& Chaush/Bulgarije.

55 Het EHRM verbiedt de overheid geloofsgemeenschappen tot fusie te dwingen. Zie bijv. recent EHRM 17 november 2017, nr. 3532/07, Orthodox Ohrid Archdiocese (Greek-Orthodox Ohrid Archdiocese of the Peć Patriarchy)/Macedonië, par. 117.

56 Vgl. ECieRM, beslissing 11 april 1996, nr. 24019/94, Finska Församlingen I Stockholm en Hautaniemi/Zweden; EHRM 15 september 2009, nr. 798/05, Mirol,ubovs e.a./Letland, par. 93. 
e geloofsgemeenschappen zelf kunnen uitmaken wie de geestelijke bedienaren en geestelijk leiders zijn, ${ }^{57}$ dezen zo nodig uit het buitenland betrekken ${ }^{58}$ en bepalen wie bevoegd is om voor de geloofsgemeenschap religieuze taken te verrichten; 59

f geloofsgemeenschappen de vrijheid hebben religieus voorgeschreven rituelen uit te voeren (bijv. besnijdenis, ${ }^{60}$ lijkbezorging, gebedsoproep, ${ }^{61}$ het religieus slachten van dieren, ${ }^{62}$ het voorhanden hebben van geestverruimende the ${ }^{63}$ );

$\mathrm{g}$ geloofsgemeenschappen de ruimte hebben voorzieningen te treffen om de gelovigen naar religieuze voorschriften te laten leven (bijv. het naleven van spijswetten $^{64}$ );

$\mathrm{h}$ geloofsgemeenschappen de ruimte hebben om de gelovigen die een beperkte bewegingsvrijheid hebben, geestelijke verzorging te bieden (met name in detentie-instellingen); ${ }^{65}$

Om deze rechten uit te kunnen oefenen, moeten de geloofsgemeenschappen desgewenst kunnen beschikken over een vorm van rechtspersoonlijkheid. ${ }^{66} \mathrm{Het}$ EHRM stelt voorts dat geloofsgemeenschappen de fondsen die benodigd zijn voor de hiervoor opgesomde activiteiten zelf vrijelijk moet kunnen verwerven, zodat hun bestaan niet onmogelijk wordt. Dit recht op vrije verwerving van gelden om het voortbestaan te garanderen, wordt ook aangeduid als een aan geloofsgemeenschappen toekomend recht op zelffinanciering. ${ }^{67}$

Nationale overheidsbemoeienis met de financiering van religie wordt door het EHRM niet onmiddellijk beschouwd als een grondrechtenaspect van collectieve godsdienstuitoefening. Het is een aangelegenheid die nauw samenhangt met de verschillende nationale kerk- en staatstelsels, een kwestie waarin staten eigen

57 EHRM 14 december 1999, nr. 38178/97, Serif/Griekenland; EHRM 26 oktober 2000, nr. 30985/96, Hasan \& Chaush/Bulgarije.

58 EHRM beslissing 14 februari 2006, nr. 25525/03, El Majjaoui \& Stichting Touba Moskee/Nederland; EHRM (Grote Kamer) 20 december 2007, nr. 25525/03, El Majjaoui \& Stichting Touba Moskee/Nederland (friendly settlement).

59 EHRM (Grote Kamer) 12 juni 2014, nr. 56030/07, Fernández Martínez/Spanje.

60 EHRM beslissing 10 juli 2001, nr. 41754/98, Johannische Kirche \& Peters/Duitsland; EHRM beslissing 18 oktober 2016, nr. 41214/13, Muslim Board Startsevo/Bulgarije.

61 EHRM beslissing 16 oktober 2012, nr. 2158/12, Schilder/Nederland.

62 EHRM (Grote Kamer) 27 juni 2000, nr. 27417/95, Cha'are Shalom ve Tsedek/Frankrijk. J. Janssen, 'Onverdoofd slachten. Dierenwelzijnargumenten tegen en godsdienstige argumenten voor deze slachtmethode', Tijdschrift voor Religie, Recht en Beleid 2014, 1, p. 34-45; G. van der Schyff, 'Onverdoofd ritueel slachten getoetst aan het EVRM: Het Deense verbod als Europees vraagstuk', Tijdschrift voor Religie, Recht en Beleid 2015, 1, p. 56-71.

63 EHRM beslissing 6 mei 2014, nr. 28167/07, Alida Maria Fränklin Beentjes en CEFLU-Luz da Floresta/Nederland.

64 EHRM (Grote Kamer) 27 juni 2000, nr. 27417/95, Cha'are Shalom ve Tsedek/Frankrijk.

65 Af te leiden uit het individuele recht op geestelijke bijstand; zie bijv. EHRM 30 november 2006, nr. 61638/00, Igors Dmitrijevs/Letland.

66 Zie bijv. EHRM 5 oktober 2006, nr. 72881/01, Moscow Branch of the Salvation Army/Rusland, par. 59.

67 EHRM 30 juni 2011, nr. 8916/05, Association les Témoins de Jehovah/Frankrijk. Cf. ECieRM 19 januari 1998, nr. 26308/95, Institut de prêtres français e.a./Turkije. 
keuzes kunnen maken. ${ }^{68}$ Vormen van directe of van indirecte staatssteun (zoals de in Nederland bestaande giftenaftrek voor anbi-instellingen) behoren daarmee niet tot het grondrechtelijke minimum dat uit het EVRM afgeleid kan worden. ${ }^{69}$ Dit betekent overigens niet dat de staat een stelsel van directe of indirecte steun naar believen kan inrichten. Uit de (op dit punt schaarse) jurisprudentie van het EHRM blijkt dat discriminerende regelingen de toets van de kritiek niet doorstaan. Als een dergelijke regeling het naakte bestaan van een geloofsgemeenschap in gevaar zou brengen, dan is dit overheidshandelen in de optiek van het EHRM in strijd met de vrijheid van godsdienst als zodanig. ${ }^{70}$ Dit roept de vraag op of het verhinderen van externe steun (bijv. steun van de Turkse staat via de Diyanet) aan Nederlandse moskeegemeenschappen niet hetzelfde oordeel kan treffen. Het miskennen van het recht op zelffinanciering is, wegens de consequenties die het heeft voor andere wezenlijke aspecten van de collectieve godsdienstbeleving, aan te merken als een beperking van de door artikel 9 EVRM beschermde godsdienstvrijheid, die zal moeten voldoen aan de in het tweede lid van deze verdragsbepaling genoemde voorwaarden.

De ruime catalogus aan deelrechten waar geloofsgemeenschappen staat op kunnen maken is niet immuun voor beperkend staatsoptreden. Daarin kent het EHRM, conform zijn vaste jurisprudentie, de nationale autoriteiten vrijwel steeds een (soms ruime) 'margin of appreciation' toe. Bovendien wordt de nationale overheid door het EHRM een bijzondere rol toegekend, die van 'neutral and impartial organiser of the practising of the various religions, denominations and beliefs', een rol die zij vervult met het oog op het realiseren van 'religious harmony and tolerance in a democratic society'. ${ }^{71}$ Uit de gekozen bewoordingen blijkt al dat de overheid hierin een eigen rol heeft, maar met inachtneming van de op dit terrein klassieke vereisten van neutraliteit en onpartijdigheid. Deze vereisten kunnen worden beschouwd als de kenmerken van de door het EHRM vereiste afstand tussen staat en de diverse levensbeschouwingen.

\section{EHRM en (buitenlandse) steun aan religie - krijtlijnen}

In de EHRM-jurisprudentie waarin religiefinanciering een rol speelt, staan vooral nationale regimes met (ook materieel) bevoorrechte kerken centraal. Hierbij waren een heel enkele maal de bevoorrechte groepen klager, ${ }^{72}$ maar meestal

68 Vaste jurisprudentie: EHRM beslissing 14 juni 2001, nr. 53072/99, J. Alujer Fernandez en R. Caballero Garcia/Spanje. Recent: EHRM 24 mei 2016, 36915/10 en 8606/13, Association de solidarité avec les témoins de Jéhovah e.a./Turkije, par. 97; EHRM 26 april 2016, nr. 62649/10, İzzettin Doğan e.a./Turkije, par. 162; EHRM 6 april 2017, nrs. 10138/11, 16687/11, 25359/11 en 28919/11, Klein e.a./Duitsland, par. 87.

69 Zie A.J. Overbeeke \& G. van der Schyff, 'Overheidsfinanciering voor geloofsgemeenschappen in de Straatsburgse jurisprudentie’, NTKR 2018, 1, p. 43-71.

70 Uitkomst in EHRM 30 juni 2011, nr. 8916/05, Association les Témoins de Jehovah/Frankrijk.

71 Zie hierover: S.C. van Bijsterveld, 'De staat als 'neutral organiser of religions? Een analyse van de rechtspraak van het Europees Hof voor de Rechten van de Mens (I)', Tijdschrift voor Religie, Recht en Beleid 2013, 1, p. 44-64; S.C. van Bijsterveld, 'De staat als 'neutral organiser of religions? Een analyse van de rechtspraak van het Europees Hof voor de Rechten van de Mens (II)': Tijdschrift voor Religie, Recht en Beleid 2013, 2, p. 34-58.

72 EHRM 9 december 1994, nrs. 13092/87, 13984/88, The Holy Monasteries/Griekenland. 
waren de klachten afkomstig van (aanhangers van) andere denominaties. Binnen die laatste categorie wordt in het merendeel van de zaken gepoogd het niet verkrijgen van één of meerdere aan bevoorrechte denominaties toegekende faciliteiten als discriminerend ${ }^{73}$ of zelfs als een directe schending van de godsdienstvrijheid $^{74}$ te beschouwen. Het EHRM was daarbij eerst erg terughoudend. In materiele kwesties nam het aanvankelijk slechts aan dat de godsdienstvrijheid in het gedrang zou kunnen komen als het ging om 'the objects intended for the celebration of divine worship', ${ }^{75}$ een standpunt dat in latere zaken niet meer terugkeert. In geen enkel geval heeft het EHRM moeten oordelen in een zaak waarin moest worden nagegaan of een staat een geloofsgemeenschap verhinderde financiering te ontvangen vanuit het buitenland. Dit betekent echter niet dat we hier, als het gaat om de EHRM-jurisprudentie, in een terra incognita verkeren. Er is immers wel jurisprudentie waarin geoordeeld moest worden over (a) overheidshandelen dat de financieringsmogelijkheden van geloofsgemeenschappen beperkt, en (b) over tegen kerkgemeenschappen gericht overheidshandelen dat mede ingegeven is door ernstige zorg om religieuze invloed vanuit het buitenland.

\section{a. Overheidsbeleid dat (zelf)financiering van geloofsgemeenschappen belemmert}

Een eerste aanknopingspunt vormt het eerdergenoemde recht op zelffinanciering, een collectief aspect van de vrijheid van godsdienst. Aantasting van het recht op zelffinanciering kan onder omstandigheden worden aangemerkt als een beperking van de godsdienstvrijheid van de geloofsgemeenschap (en van haar leden). Het recht op zelffinanciering is een recht dat voorwaardenscheppend is en het mogelijk moet maken dat collectieve godsdienstuitoefening mogelijk is (zie paragraaf 'Grondrechten van geloofsgemeenschappen in het geding').

Precies op dit punt is er lering te trekken uit jurisprudentie die voortkomt uit een zaak over fiscale voordelen die een geloofsgemeenschap geniet bij het ontvangen van giften uit de eigen achterban, een regeling die noch volledige zelffinanciering noch directe staatssteun inhoudt, zoals blijkt uit het EHRM-arrest Association Les Témoins de Jéhovah/Frankrijk. ${ }^{76}$

In deze zaak stond de giftenaftrek voor donaties aan de geloofsgemeenschap van Jehova's getuigen centraal, een vorm van indirecte staatssteun. Naar aanleiding van een overheidsrapport over sekten (waarin de Jehova's getuigen waren genoemd) bedacht de Franse overheid dat (strengere) belastingcontroles zouden kunnen bijdragen aan het ontregelen van sekten en zo een eerste stap zouden kunnen vormen naar de ontbinding ervan. Het leidde ertoe dat de vereniging van Jehova's getuigen een belasting werd opgelegd (een naheffing van ruim $€ 45$ miljoen) over bedragen die in haar boekhouding als 'giften' waren geregistreerd. De vereniging stelde dat de naheffing op de ontvangen giften in strijd was met haar vrijheid van godsdienst en bovendien discriminatoir moest worden geacht. 
Als beoordelingsmaatstaf gebruikte het EHRM in deze zaak het effect van dit overheidshandelen, namelijk het effect dat het door dit handelen de geloofsgemeenschap onmogelijk zou worden gemaakt om materieel voort te bestaan. ${ }^{77}$ De aan de geloofsgemeenschap opgelegde naheffing had volgens het Hof in deze omstandigheden als vermoedelijk gevolg dat gebouwen bestemd voor de eredienst afgestoten hadden moeten worden. ${ }^{78}$ De impact van de maatregel op de godsdienstuitoefening was aanzienlijk en objectiveerbaar. ${ }^{79}$ In deze situatie achtte het Hof die impact zo groot dat de uitoefening van de godsdienstvrijheid van deze gemeenschap vrijwel onmogelijk wordt gemaakt, zelfs al gaat het in wezen slechts om een niet toekennen van een fiscaal voordeel. Hier stond het voortbestaan van de geloofsgemeenschap naar het oordeel van het Hof op het spel.

Het arrest Association Les Témoins de Jéhovah/Frankrijk is van belang voor de in deze bijdrage behandelde kwestie. Het Hof hanteert een (strenge) impacttoets in een zaak waar de overheid éigen indirecte steun onthoudt aan een geloofsgemeenschap; dit gebeurt op een manier die het de gemeenschap moeilijk maakt via zelffinanciering in de bouw en het behoud van haar bedehuizen te voorzien. De maatregel verschilt qua impact van het overheidsoptreden niet wezenlijk van de situatie dat een overheid de zelffinanciering bemoeilijkt (en eventueel een geloofsgemeenschap financieel drooglegt) door het beletten van buitenlandfinanciering.

In de beoordeling van het Hof was niet de herkomst van de aan de geloofsgemeenschap onthouden middelen van betekenis, maar de vraag of overheidsoptreden de financieringsmogelijkheden van een geloofsgemeenschap zo fors aantast dat zo het voortbestaan van de geloofsgemeenschap in het gedrang komt. Dit betekent niet dat de herkomst van de middelen in het geheel geen betekenis heeft. Daar waar het, zoals in de Franse zaak, het niet toekennen van indirecte Franse overheidssteun betreft, ${ }^{80}$ is het overheidsoptreden minder problematisch dan in een zaak waar het gaat om het van overheidswege verhinderen van louter zelffinanciering, bijvoorbeeld bij het belemmeren van buitenlandfinanciering. In het eerste geval is het in beginsel aan de nationale overheid om de keuze te

77 Het Hof is minder streng in het recentere arrest EHRM, 8 april 2014, nrs. 70945/11, 23611/12, 26998/12, 41150/12, 41155/12, 41463/12, 41553/12, 54977/12, 56581/12, Magyar Keresztény Mennonita Egyház e.a./Hongarije. Daar wordt niet het gevaar voor het voortbestaan als 'impact'toets gebruikt, maar de mogelijke last ('burden') die het door de staat ontnemen van een financieringsmogelijkheid voor de geloofsgemeenschap inhoudt. Zie over deze wijziging in de impacttoets: Overbeeke \& Van der Schyff 2018, p. 56-58.

78 EHRM 30 juni 2011, nr. 8916/05, Association Les Témoins de Jéhovah/Frankrijk, par. 52-53. Zie verder EHRM 31 januari 2013, nr. 50615/07, Association des Chevaliers du Lotus d'Or/Frankrijk, par. 33-34; EHRM 31 januari 2013, nr. 25502/07, Eglise Evangélique Missionnaire et Salaûn/Frankrijk, par. 28-29; EHRM 31 januari 2013, nr. 50471/07, Association Culturelle du Temple Pyramide/Frankrijk, par. 34-35; EHRM 4 maart 2014, nr. 7552/09, The Church of Jesus Christ of Latter-Day Saints/Verenigd Koninkrijk, par. 30.

79 Zoals al is aangegeven in de annotatie bij EHRM 30 juni 2011, nr. 8916/05, Association Les Témoins de Jéhovah/Frankrijk, EHRC 2011/128, m.nt. Groen.

80 Een steun waartoe de verdragsstaten niet gehouden zijn. EcieRM 11 januari 1992, nr. 17522/90, Iglesia Bautista 'El Salvador' \& José Aquilino Ortega Moratilla/Spanje (vaste jurisprudentie). 
maken voor een stelsel waarin geloofsgemeenschappen fiscale voordelen genieten.

Het komt me voor dat de in deze zaak gehanteerde redeneerlijn ook van betekenis is bij de beoordeling van overheidsoptreden dat geloofsgemeenschappen belet uit het buitenland steun te ontvangen ten behoeve van godsdienstige activiteiten. Een dergelijke ingrijpende maatregel, die onder artikel 9 EVRM een beperking van de vrijheid van godsdienst inhoudt, zal - wil zij de toets van Straatsburg (afgeleid uit de zaak Association Les Témoins de Jéhovah/Frankrijk) doorstaan - moeten voldoen aan de vereisten van artikel 9 lid 2 EVRM.

\section{b. Overheidsbeleid dat beoogt buitenlandse invloed tegen te gaan}

In de tweede plaats is de positiekeuze van het Hof van belang in de zaken waarin overheidshandelen beoordeeld wordt dat is ingegeven door de wens buitenlandse invloed in het nationale religieuze leven uit te bannen of te beperken. In enkele kwesties die tot een oordeel van het EHRM leidden was sprake van overheidsbeleid dat buitenlandse invloed wil tegengaan omdat die invloed het land zou kunnen ontwrichten. Het gaat dan om overheidsbeleid dat, positiever uitgedrukt, integratie nastreeft. Het is een beleidsmotief dat gewicht heeft in het Nederlandse debat, of het nu gaat om als salafistisch of als nationalistisch aangemerkte moskeeën.

Een vroege uitspraak waarin deze problematiek speelde, was die in de zaak Metropolitan Church of Bessarabia e.a./Moldavië, ${ }^{81}$ die in 2001 een leidend arrest opleverde op het terrein van de organisatie-autonomie van geloofsgemeenschappen. Het feitencomplex toont echter ook een grensoverschrijdend element dat voor deze bijdrage van belang is. De Moldavische overheid wilde verhinderen dat Roemenië invloed verwierf in orthodoxe geloofsgemeenschappen van Moldavië, een invloed die naar inschatting van de overheid ontwrichtend zou uitpakken voor het land. ${ }^{82}$ In de optiek van de Moldavische overheid werkte deze buitenlandse (religieuze) invloed integratie tegen, en zou juist tot desintegratie leiden. In Moldavië en Roemenië leeft immers een streven naar hereniging van beide landen. ${ }^{83}$ Er stond dus veel op het spel: de klagende partij, die voor het EHRM de erkenningsweigering van de Moldavische overheid aanvecht, is een geloofsgemeenschap die zich immers aan vreemd gezag onderschikt - dat van de door de Roemeense staat gefinancierde Roemeense Orthodoxe Kerk - en mede daarom geen erkenning verwierf. De overheid stelde bovendien dat de klager religieuze en poli-

81 EHRM 13 december 2001, nr. 45701/99, Metropolitan Church of Bessarabia e.a./Moldavië.

82 Idem, par. 98 en 111.

83 Zie J. Rankin, 'Moldova PM rules out reunification with Romania', The Guardian 11 mei 2018, www.theguardian.com/world/2018/may/11/moldova-pm-pavel-filip-rules-out-reunificationromania. 
tieke activiteiten vermengde. ${ }^{84}$ Het werd de kerkgemeenschap aldus onmogelijk gemaakt te functioneren.

Het EHRM gaat in de redenering van de overheid mee, in die zin dat het aanvaardt dat de overheidsmaatregel een legitiem doel dient. Een staat is bevoegd na te gaan of een beweging of een vereniging - onder het mom van religie-uitoefening - activiteiten uitoefent die schadelijk zijn voor de bevolking of voor de openbare veiligheid. ${ }^{85}$ Het Hof oordeelt dat het overheidsoptreden in de gegeven omstandigheden een legitiem doel beoogt: de bescherming van de openbare orde en de openbare veiligheid. ${ }^{86}$ Het Hof komt vervolgens, na afweging van de verregaande consequenties van het overheidshandelen (de erkenningsweigering) tegen deze legitieme doelen, tot de vaststelling dat ze disproportioneel zijn, zodat tot schending van artikel 9 EVRM geconcludeerd wordt. ${ }^{87}$

In de zaak Moscow Branch of The Salvation Army/Rusland (2007) ${ }^{88}$ beoordeelde het EHRM het gewicht van een Russische maatregel tegen buitenlandse invloed op in Rusland gevestigde geloofsgemeenschappen. De motieven voor deze maatregel verschillen enigszins van die van de Moldavische overheid in de zaak Metropolitan Church of Bessarabia en zijn, in de woorden van Jan-Peter Loof, ingegeven door 'Russische beschermdrift van de nationale orthodoxe kerk'. ${ }^{89}$ Een herregistratie van de Moskouse afdeling van het Leger des Heils stuitte onder meer op het bezwaar dat deze hiërarchisch georganiseerde organisatie vanuit Londen werd geleid, ${ }^{90}$ een bezwaar dat in het licht van de Russische religiewetgeving uiteindelijk geen stand houdt. ${ }^{91}$ Het Hof neemt deze gelegenheid te baat om een ander, verwant, element uit deze wetgeving onder kritiek te stellen, het verbod voor vreemdelingen om in Rusland religieuze organisaties te stichten. Voor dat verbod, dat een op nationaliteit gebaseerd verschil in behandeling in het leven riep op het punt van de mogelijkheid de godsdienstvrijheid uit te oefenen door het deelnemen aan het leven van georganiseerde geloofsgemeenschappen, bestond volgens het Hof geen redelijke en objectieve rechtvaardiging. ${ }^{92}$ De bezwaren met betrekking tot de 'foreign origin' die mede aan de basis lagen van het belemmeren van

84 Letterlijk: 'under cover of the applicant Church, which was subordinate to the patriarchate of Bucharest, political forces were at work, acting hand-in-glove with Romanian interests favourable to reunification between Bessarabia and Romania'. EHRM 13 december 2001, nr. 45701/99, Metropolitan Church of Bessarabia e.a./Moldavië, par. 113.

85 Idem, par. 113 (vaste rechtspraak); zie (ook over maatregelen tegen in het buitenland gevestigde kerkgenootschappen) EHRM 5 april 2007, nr. 18147/02, Church of Scientology Moscow/Rusland.

86 EHRM 13 december 2001, nr. 45701/99, Metropolitan Church of Bessarabia e.a./Moldavië, par. 113.

87 Idem, par. 130.

88 EHRM 5 oktober 2006, nr. 72881/01, Moscow Branch of The Salvation Army/Rusland.

89 J.-P. Loof, 'Traineren van buitenlandse religieuze genootschappen in Rusland: schending artikel 11 juncto 9 EVRM' (annotatie EHRM 5 oktober 2006, nr. 72881/01, Moscow Branch of The Salvation Army/Rusland en EHRM 5 april 2007, nr. 18147/02, Church of Scientology Moscow/Rusland), NJCM-Bulletin 2007, 6, p. 856.

90 EHRM 5 oktober 2006, nr. 72881/01, Moscow Branch of The Salvation Army/Rusland, par. 81.

91 Idem, par. 83.

92 Idem, par. 82. 
de herregistratie van de Moskouse afdeling van het 'vreemde' kerkgenootschap, overtuigden het Hof niet. ${ }^{93}$

In dit type zaken, die raken aan de nationale keuzes met betrekking tot de verhoudingen tussen kerk en staat, maar waar tegelijkertijd de religieuze pluriformiteit op het spel staat, wordt een beperking op de organisatievrijheid, die mede beschermd is door de vrijheid van vereniging (art. 11 EVRM), strikt getoetst. ${ }^{94}$ Hier wordt, zoals in de Russische zaak in algemene termen wordt gesteld, aan verdragsstaten slechts een geringe margin of appreciation gelaten. ${ }^{95}$ Naar aanleiding van deze stellingname merkte Loof ruim tien jaar geleden al op: 'Gelet op de geluiden die af en toe in de Nederlandse politiek opklinken als het gaat om optreden jegens organisaties van buitenlandse oorsprong (vooral Islamitische) vanwege opvattingen of gebruiken die bij ons niet mainstream zijn, kan het geen kwaad dat nog eens onder de aandacht te brengen. ${ }^{96}$

Met Loofs kanttekening belanden we bij de actuele Nederlandse politieke constellatie, nu immers op dit terrein in het regeerakkoord van oktober 2017 overheidsoptreden in het vooruitzicht wordt gesteld. Of dit overheidsbeleid verenigbaar zal zijn met de verplichtingen die Nederland heeft onder artikel 9 EVRM, moet worden afgewacht. De door de regering aangekondigde verkenning zal hierover uitsluitsel kunnen geven. Uit het voorafgaande kan al wel worden opgemaakt dat, hoewel er in Straatsburg nooit geoordeeld is over het door lidstaten belemmeren van buitenlandfinanciering, de hoger behandelde EHRM-jurisprudentie over andere vormen van financieringsbelemmering en over het belemmeren van buitenlandse invloed richtinggevend zou kunnen zijn bij het bepalen van wat geoorloofd is bij het raken aan het recht op zelffinanciering van geloofsgemeenschappen.

In een afsluitend deel wordt een balans opgemaakt. Is het denkbaar dat Nederland het Oostenrijkse voorbeeld uit 2015 volgt en structurele buitenlandfinanciering van islamitische geloofsgemeenschappen onmogelijk maakt, zoals een Kamermeerderheid in 2016 met betrekking tot de Turkse Diyanet-moskeeën voorstelde? Of moet worden aangenomen dat er een bescheidener maatregel wordt getroffen?

\section{Concluderend}

Als het gaat om overheidsbeleid met betrekking tot het financieren van geloofsgemeenschappen is het EHRM helder, ook al laat het de verdragsstaten veel ruimte

93 Het EHRM oordeelde dat 'the arguments pertaining to the applicant's alleged "foreign origin" were neither "relevant and sufficient" for refusing its re-registration, nor "prescribed by law"'. Idem, par. 86 (schending art. $9 \mathrm{j}^{\circ} 11$ EVRM)

94 Idem, par. 61-62 en 76-77.

95 Idem, par. 76. Het Hof toetst hierbij intensief: 'it must look at the interference complained of in the light of the case as a whole and determine whether it was "proportionate to the legitimate aim pursued" and whether the reasons adduced by the national authorities to justify it are "relevant and sufficient"'. Idem, par. 76. 
in het bepalen van het kerk- en staat-regime: financieringskwesties vallen niet buiten het beschermingsbereik van artikel 9 EVRM. Overheidsmaatregelen die aan de financiering van een geloofsgemeenschap raken, kunnen de godsdienstvrijheid in het gedrang brengen. Het recht op collectieve godsdienstbeleving impliceert een recht op zelffinanciering. In stelsels waarin geloofsgemeenschappen geen staatssteun ontvangen, weegt dit recht uit de aard der zaak bijzonder zwaar. Dit is relevant voor het Nederlandse stelsel; daarin wordt van geloofsgemeenschappen verwacht dat ze het zonder Nederlandse staatssteun moeten zien te rooien. Zelffinanciering is het uitgangspunt. In Nederland geldt met andere woorden een stelsel waarin scheiding van kerk en staat inhoudt dat de Nederlandse overheid geen financiële verantwoordelijkheid kan nemen voor het (voort)bestaan van geloofsgemeenschappen.

Dit zegt niets over de keuzes van andere staten; deze kunnen hun geloofsgemeenschappen financieren, ook geloofsgemeenschappen die in de diaspora verkeren, bijvoorbeeld in Nederland. Die steun kan ook bestaan in het zenden van door een overheid gefinancierde geestelijke bedienaren, zoals het geval is met de imams in Nederlandse Diyanet-moskeeën (of - om een minder omstreden voorbeeld te geven - met Noorse dominees van de Noorse kerken in Nederland). Een Nederlands stelsel dat inhoudt dat de Nederlandse overheid geloofsgemeenschappen niet financiert, impliceert niet dat in Nederland opererende geloofsgemeenschappen geen steun kunnen ontvangen vanuit het buitenland, ook niet als die verleend wordt door andere staatsoverheden. ${ }^{97}$

Die steun kan een belangrijke component vormen van de zelffinanciering die van geloofsgemeenschappen in Nederland verwacht wordt. In die zin kan worden ingestemd met de positiekeuze van het vorige kabinet (Rutte II): buitenlandse financiering is in beginsel een zaak van vrijheid en daarmee spelen grondrechten hier een rol. Die reflex was zelfs aanwezig bij een in 2002 ingediende motie van Wilders c.s. over fundamentalistische financiering vanuit het buitenland, waarin de regering verzocht werd 'met inachtneming van de grondwettelijke vrijheden, te onderzoeken wat de mogelijkheden zijn om te komen tot een verbod op internationale geldstromen uit militant fundamentalistische hoek' (mijn cursivering; AO). ${ }^{98}$

Uit de Straatsburgse jurisprudentie kan ook worden afgeleid dat de overheid buitenlandse religieuze invloed zou kunnen tegengaan wegens de dreiging die daarvan uitgaat, met name als gevreesd moet worden dat deze desintegratief uitpakt en de eenheid van het land erdoor op het spel gezet wordt (de casus in het arrest Metropolitan Church of Bessarabia e.a./Moldavië). Een dergelijke vrijheidsbeperking heeft een legitiem doel: de bescherming van de openbare orde en de openbare veiligheid. ${ }^{99}$ Deze maatregel, die een legitiem doel zou dienen, moet voldoen aan alle vereisten van artikel 9 lid 2 EVRM. De beperking moet, wil ze gerecht-

97 In die zin is de herdefiniëring van wat 'scheiding kerk en staat' zou betekenen in de motie-Buma c.s. (Kamerstukken II 2016/17, 29279, 155) onjuist.

98 Motie Wilders c.s. (over onderzoek naar de mogelijkheid buitenlandfinanciering door fundamentalistische organisaties te weren), Kamerstukken II 2002/03, 27925, 76.

99 EHRM 13 december 2001, nr. 45701/99, Metropolitan Church of Bessarabia e.a./Moldavië, par. 113. 
vaardigd zijn, ook 'noodzakelijk zijn in een democratische samenleving'. Het EHRM hanteert daarbij een strikte proportionaliteitstoets, waarbij het vrijheidsbeperkende optreden van de verdragsstaat aantoonbaar noodzakelijk moet zijn, waarbij het Hof ook toetst of de activiteiten die de grond zijn voor het overheidsoptreden aan de door de vrijheidsbeperking getroffen geloofsgemeenschap aangerekend worden. De lat ligt daarbij hoog; de maatstaven die het EHRM hanteert zijn vergelijkbaar met deze die gelden voor partijverboden.

Uit het in 2017 gesloten regeerakkoord blijkt dat de coalitie meent dat zich in Nederland een situatie voordoet die het noodzakelijk maakt dat er bij de financiering van moskeeën voor grotere financiële transparantie wordt gezorgd - een element dat geen grondrechtenvragen oproept - en waarbij wordt aangestuurd op het verhinderen van buitenlandfinanciering zodra de steun uit 'onvrije landen' komt. Bij dit laatste voornemen ontbreekt de uitdrukkelijke grondrechtendisclaimer waarvan de kabinetsstandpunten over deze kwestie eerder steeds waren voorzien. Met enige goede wil kan die echter worden 'ingelezen' in de tekst van het regeerakkoord, aangezien daarin met regelmaat gewezen is op het belang van vrijheden in een democratische rechtsstaat. ${ }^{100}$ Bij het uitwerken van een beleid dat buitenlandfinanciering tegengaat, kan van het kabinet-Rutte III verwacht worden dat er een regeling wordt vastgesteld die voldoet aan de strenge toets die de Straatsburgse jurisprudentie aanlegt. Belemmering van buitenlandse financiering zal mogelijk zijn, maar deze maatregel zal specifieke, concrete gevallen moeten treffen en bovendien moeten deugen in het licht van het principe van gelijke behandeling. ${ }^{101}$ Een algemeen verbod op staatssteun voor Diyanet-moskeeën vanuit Turkije, zoals de Kamer nog in 2016 wenste, is dan niet haalbaar. Zelfs de loutere herkomst van de geldmiddelen, geld afkomstig uit de categorie 'onvrije landen', zal niet doorslaggevend zijn bij het verantwoorden van een beperking op het recht op zelffinanciering van een geloofsgemeenschap, tenzij aangetoond kan worden dat het accepteren van geld uit deze landen uit de aard der zaak verwijtbaar is. De introductie van een verbodsreglementering vergt ook dat helder wordt gemaakt wat de 'onvrije landen' zijn waarvan de steun in de optiek van de Nederlandse overheid als 'ongewenst' zou moeten worden afgewezen.

Als zelffinanciering belemmerd wordt, is de impact daarvan op het bestaan van de geloofsgemeenschap van belang. Hoe groter de impact hoe groter de vrijheidsbeperking en hoe zwaarder de verantwoording van de vrijheidsbeperking. De ook in het regeerakkoord (in het kader van het te voeren cultuurbeleid) aangekondigde handhaving van de Geefwet impliceert het handhaven van de indirecte staatssteun aan geloofsgemeenschappen die de anbi-status verwerven. Deze regelgeving ondersteunt zelffinanciering vanuit de eigen Nederlandse achterban en kan een stimulans betekenen voor een minder repressieve aanpak van het probleem van de financiële afhankelijkheid van buitenlandse steun. Bovendien draagt deelname aan het systeem van de giftenaftrek bij aan de - ook in het regeerakkoord genoemde - grotere financiële transparantie.

100 Zie Vertrouwen in de toekomst. Regeerakkoord 2017-2021, 10 oktober 2017, p. 1, 2, 3, 4, 19, 54.

101 Zie de analyse in F. Jensma, “'Onze vrijheden” komen ook toe aan moskeeën', NRC 5 mei 2018, www.nrc.nl/nieuws/2018/05/05/onze-vrijheden-komen-ook-toe-aan-moskeeen-a1601921. 